\title{
Assessing the sustainability of traditional agroforestry practices: a case of Mamar agroforestry in Kupang-Indonesia
}

\author{
Alfred Umbu Kuala Ngaji ${ }^{1,2}$, Muhammad Baiquni ${ }^{3,4}$, Hatma Suryatmojo ${ }^{5}$ and Eko Haryono ${ }^{3,4 *}$ \\ 1 Student of Environmental Science Doctorate Program, Universitas Gadjah Mada, Yogyakarta, Indonesia \\ 2 State Agriculture Polytechnic of Kupang, Nusa Tenggara Timur, Indonesia \\ 3 Faculty of Geography, Universitas Gadjah Mada, Yogyakarta, Indonesia \\ 4 Graduate School, Universitas Gadjah Mada, Yogyakarta, Indonesia \\ 5 Faculty of Forestry, Universitas Gadjah Mada, Yogyakarta, Indonesia \\ * Correspondence author: e.haryono@ugm.ac.id; Tel.: +62-812 2711480
}

\begin{abstract}
A traditional agroforestry of West Timor, namely Mamar, produces important ecosystem services to the people of this arid region, however, its management tends to change, thereby disrupting its sustainability. This study aims to assess the sustainability of Mamar agroforestry by analyzing the livelihood assests of the community, the biophysical land performance of the soil, and the value of ecosystem services. Furthermore, data, on perception and livelihood assets; the level of soil damage, the importance value index, and diversity index, the value of ecosystem services based on the opinion of experts and community leaders, as well as change in land use were collected in five villages in Kupang district using surveys with a qualitative and quantitative approach. The results showed a change of perspective in Mamar's management; the decrease in the important value index of cultural crops, the diversity index is classified as declining, there is soil damage in several parameters, and the value of ecosystem services does not focus on cultural services. Considering this result, there is a socio-ecological trade-off that reduces support for the sustainability of Mamar as traditional agroforestry that emphasizes socio-cultural functions.
\end{abstract}

Keywords: Sustainability; traditional agroforestry; ecosystem services; socio-ecological; trade-off; arid region

\section{Introduction}

Paying attention to ecosystem services is important and almost a necessity in the context of the sustainability of human life and other living things on this earth. Furthermore, natural resources and the environment are also very important supporting factors in this context, therefore the aspect of sustainability needs to be considered during the utilization. On the other hand, humans also condition their environment to suit their needs.

Agroforestry has long been recognized as the human-made agricultural system developed through the combination of forest plants, croaps, and livestock/fish (Mayrowani \& Ashari, 2016) and also as a producer of ecosystem services. The combination of these three elements allows humans to give the best to support their survival. Agroforestry has many positive impacts on the environment, such as in land use thereby causing it to have ecological, economic, and social advantages as stated by Ruhimat, (2015), therefore its sustainability needs to be maintained. On the other hand, Castro (2016); Graves et al. (2007); Rigueiro-Rodríguez et al. (2012) mentioned the capability of agroforestry to sustainably increase the productivity and profitability of land.

Mamar is the local Timorese term for traditional agroforestry in the west territory (Roshetko \& Mulawarman, 2002). Furthermore, it is also known as the local wisdom of the community-based farming management model which takes environmental sustainability into account. The word Mamar which means to eat betel (Natonis, 2008; Sumu, 2011), indicates the existence of a sociocultural function because betel and areca nut are important parts of West Timor culture the culture of the people of West Timor. Therefore, the existence of betel and areca plants is a special feature of Mamar. The awareness of people from West Timor on the limited carrying capacity and capacity of their territory (ecological function) results in Mamar since the dry climate and arid soil-provides many benefits to support their lives. Local social mechanisms and worldview are mentioned by Berkes et al., (2000) as a major consideration in the management of community land resources. 
Also, people tend to value and defend their way of life and land as they are considered important, even when they survive extreme weather conditions (Petheram et al., 2010; Wolf et al., 2013). Furthermore, Njurumana et al., (2008) stated that the important characteristics of Mamar agroforestry include (a) high composition and diversity of plant species; (b) its management integrates social, economic, and ecological aspects including spring protection. Some of the benefits of Mamar include the conservation of water and land sources and providing ecosystem services (Pujiono et al., 2013) which are defined as the direct or indirect benefits that humans derive from ecosystems (MA, 2005). These ecosystem services provide a communication platform between humans and nature (Wang et al., 2019). With regards to the agricultural sector, Fraser et al. (2011) and Intergovernmental Panel on Climate Change (2013) stated that people on dry land are the most vulnerable as it has an impact on soil fertility and dryland ecosystems. On the other hand, Zomer et al. (2016) also stated that agroforestry systems have an important contribution to mitigating climate change. Thus, Mamar has socio-cultural and ecological functions, so it is important to maintain its sustainability.

Over time, several conditions have the potential of disrupting the sustainability of Mamar in West Timor in general, and these disorders are divided into two types, namely natural and anthropogenic (Lu et al., 2015). Socio-economic threats which are identified as social driving forces as stated by Liu et al. (2019) in bibliometric analysis are namely, pressure on climatic change (Fraser et al., 2011; Intergovernmental Panel on Climate Change, 2013; Moss et al., 2010), rapid population growth (Muta'ali, 2019), changes in lifestyle (Ngaji et al., 2020), and government policies (Ngaji et al., 2020; Tjoe, 2016). Furthermore, the current covid-19 pandemic has the potential to disrupt the existence of Mamar because of the demands of fulfilling the necessities of life.

However, given the importance of Mamar for people's lives as well as its natural and anthropogenic disturbances, the question is, what is the current status of Mamar's sustainability, especially in its socio-cultural and ecological functions? The state of sustainability is assessed by examining asset ownership, which describe the livelihood trends of the community, the biophysical conditions of the Mamar, and the valuable ecosystem services in the area. Therefore, this study aims to assess the sustainability of Mamar in Kupang Regency based on an analysis of community livelihood assets, land biophysics, and the value of ecosystem services.

\section{Methods}

This study was conducted from September 2020 - February 2021 in Baumata and Oeletsala village, Taebenu sub-district, Camplong II village, Fatuleu sub-district, Buraen village, Amarasi Selatan sub-district, and Manubelon village, Amfoang Barat Daya sub-district, Kupang district. The location is purposively determined by considering two things, namely: (1) the presence of Mamar; (2) the distribution of locations in the Kupang district. The distribution of research locations is presented in Figure 1.

The tools and materials used are GPS, roller meter, interview guide, Landsat 5 satellite imagery in 2000 and 2010 as well as $8 \mathrm{OLI}$ in 2015 and 2020, Haga meter, ring sampler, ArcGIS 10.3., Expert SA.

The method used was a survey with both qualitative and quantitative approaches, and the data collected, consisted of three types, namely (1) social, which includes community perceptions about Mamar in their place and ownership of livelihood assets (2) biophysical, which consists of (a) an index of importance to Mamar at this location, to obtain an overview of the main vegetation of areca nut as the main element of Mamar (b) Shannon-wiener diversity index, which aims to assess the level of vegetation diversity in amber, and (c) the level of soil damage for biomass production, which is intended to obtain a picture of the intensity of activity on Mamar land, (3) changes in the value of ecosystem services $\left(\mathrm{V}_{\text {change }}\right)$ with a review of villages using an analysis of Landsat imagery for 2000, 2010, 2015, and 2020. 


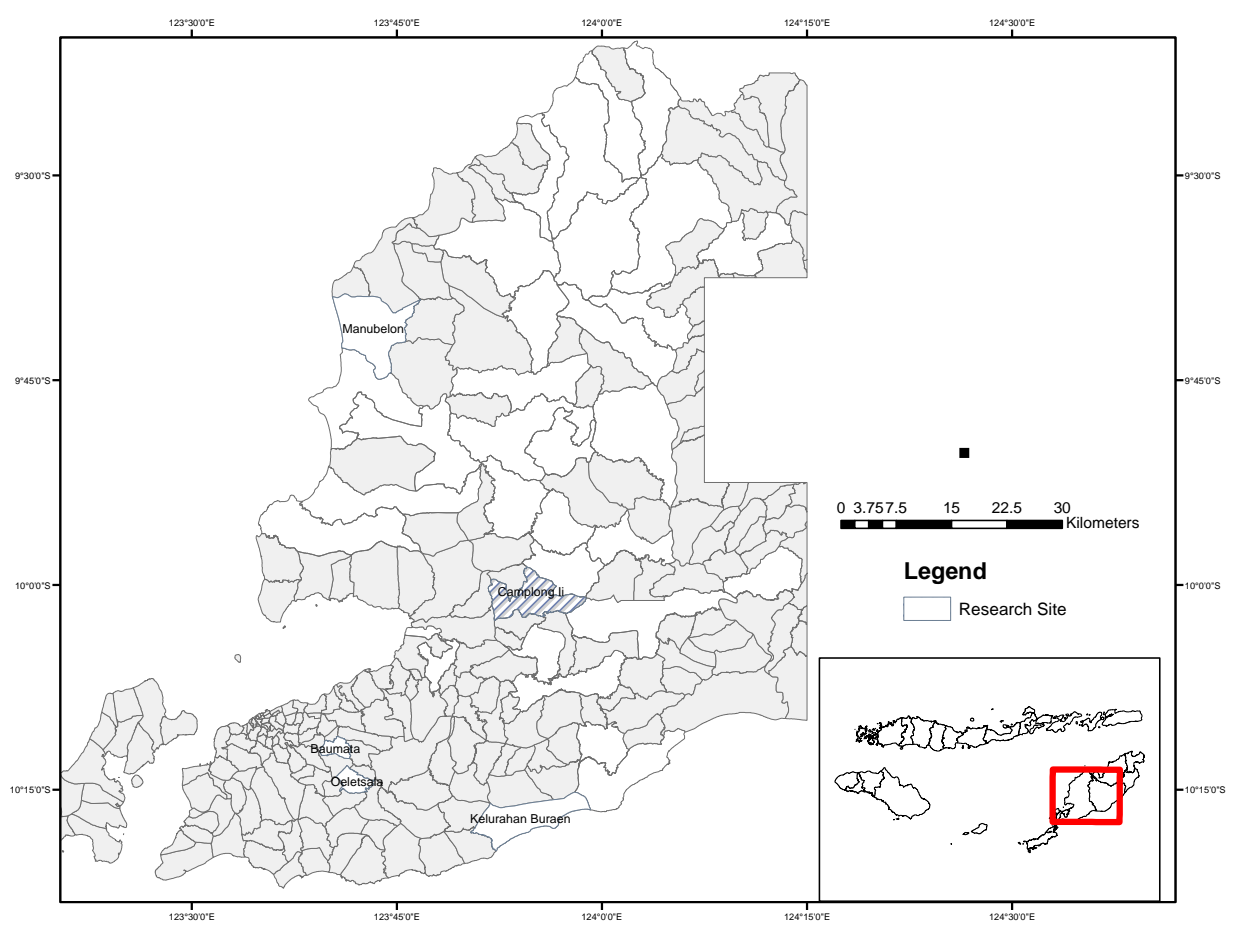

Figure 1. The study areas are evenly distributed in the Kupang district and have Mamar to provide a more comprehensive picture

\subsection{Livelihood assets mapping and community perceptions}

The collection of data on community perceptions and asset mapping was conducted through in-depth interviews and focus group discussions with ten people in each village, which are community leaders and ordinary people that have the right to Mamar and live around Mamar. The main question when collecting this perceptual data focuses on the development of the existing Mamar in their place and their effect. Furthermore, the data obtained were then analyzed qualitatively and descriptively to identify and describe the development trend of Mamar and the impact on society.

The asset mapping is conducted with reference to DFID (Department for International Development) in British Government, namely Human Capital (HC), Natural Capital (NC), Physical Capital (PC), Financial Capital (FC), and Social Capital (SC). The data is then mapped to the pentagon assets.

\subsection{Importance Value Index Observation}

The purpose of observing the Importance Value Index (IVI) is to determine the composition constituents and the types of plants in Mamar at each plant phase (seedlings, saplings, polishes, and trees), however, these studies only discuss the poles and trees phase. For this observation, a $2 \times 2$ measuring plot, was used; $5 \times 5,10 \times 10$, and $20 \times 20 \mathrm{~m}$. Since Mamar is closely related to meeting the social needs of the community, namely the existence of areca plants, more attention is focused on the existing population of areca plants, which is also used as an indicator of an assessment of the level of sustainability of the existing Mamar. The calculation of IVI is conducted based on the formula of Mueller (1974, in Njurumana, 2009).

$$
\mathrm{IVI}=\mathrm{RD}+\mathrm{RF}+\mathrm{RDom}
$$

where RD = Relative Density; RF = Relative Frequency; RDom = Relative Dominance.

Relative Density is the percentage density of a species to the density of all species. The RD value is calculated using the following formula. 


$$
R D=\frac{\text { The density of a type }}{\text { The density of all types }} \times 100 \%
$$

Calculation of the frequency of a species by comparing the number of plots found in a species with the total number of plots. RF is calculated using the following formula.

$$
R F=\frac{\text { The frequency of a type }}{\text { Frequency of all types }} \times 100 \%
$$

Relative Dominance data is obtained from the percentage of the dominance of a species to the dominance of all species. The DR value is calculated using the following formula.

$$
R D o m=\frac{\text { Dominance of a type }}{\text { Dominance of all types }} \times 100 \%
$$

\subsection{Diversity Index Observation}

A diversity index is used to measure community stability, namely the ability of a community to keep itself stable even though there are disturbances to its components. The diversity of species is calculated using the Shannon-Wiener diversity index, with the formula:

$$
\begin{aligned}
& \mathrm{H}^{\prime}=-\sum \mathrm{Pi} \ln (\mathrm{Pi}) \text {, where } \mathrm{Pi}=(\mathrm{ni} / \mathrm{N}) \\
& \text { Notes: } \quad H^{\prime}=\text { Shannon-Wiener diversity index } \\
& \mathrm{ni}=\text { Number of individuals of type } \mathrm{i} \\
& \mathrm{N}=\text { The number of individuals of all types }
\end{aligned}
$$

The criteria for categorizing the index are:

$$
\begin{aligned}
& \mathrm{H}^{\prime}<1 \quad \text { : low diversity } \\
& 1<\mathrm{H}^{\prime} \leq 3: \text { moderate diversity } \\
& \mathrm{H}^{\prime}>3 \quad \text { : high diversity }
\end{aligned}
$$

\begin{tabular}{|c|c|c|c|}
\hline Parameter & Critical threshold & Method & Tool(s) \\
\hline 1 Solum thickness & $<20 \mathrm{~cm}$ & Direct measurement & tape measure \\
\hline 2 Surface rock & $>40 \%$ & $\begin{array}{l}\text { Direct measurement of rock } \\
\text { and soil balance in area units }\end{array}$ & $\begin{array}{l}\text { tape measure; counter } \\
\text { (line or total }\end{array}$ \\
\hline 3 Fraction's composition & $\begin{array}{l}<18 \% \text { colloid; } 80 \% \\
\text { quartzitic sand }\end{array}$ & Sand colour; gravimetric & Measuring tube; scale \\
\hline 4 Volume density & $>1.4 \mathrm{~g} / \mathrm{cm}^{3}$ & Gravimetric in volume units & $\begin{array}{l}\text { Measuring tube; ring } \\
\text { sampler }\end{array}$ \\
\hline 5 Total porosity & $<30 \% ;>70 \%$ & $\begin{array}{l}\text { Calculation of volume density } \\
\text { and specific weight }\end{array}$ & $\begin{array}{l}\text { pycnometer; analytical } \\
\text { scale }\end{array}$ \\
\hline 6 Permeability & $\begin{array}{l}<0.7 \mathrm{~cm} / \mathrm{h} ;>8.0 \\
\mathrm{~cm} / \mathrm{h}\end{array}$ & Permeability & $\begin{array}{l}\text { Ring sampler; double } \\
\text { ring; permeameter }\end{array}$ \\
\hline $7 \mathrm{pH}\left(\mathrm{H}_{2} \mathrm{O}\right) 1: 2.5$ & $<4.5 ;>8.5$ & Potentiometric & $\begin{array}{l}\text { pH meter; } \mathrm{pH} \text { stick } \\
\text { scale } 0.5 \text { unit }\end{array}$ \\
\hline 8 Electrical conductivity & $>4.0 \mathrm{mS} / \mathrm{cm}$ & Electrical resistance & EC meter \\
\hline 9 Redox & $200 \mathrm{mV}$ & Electrical voltage & $\begin{array}{l}\mathrm{pH} \text { meter; platinum } \\
\text { electrodes }\end{array}$ \\
\hline $\begin{array}{l}\text { The number of } \\
\text { microbes }\end{array}$ & $<10^{2} \mathrm{cfu} / \mathrm{g}$ & Plating technique & $\begin{array}{l}\text { petri dishes; colony } \\
\text { counter }\end{array}$ \\
\hline
\end{tabular}

\subsection{Soil damage for biomass production}

The variables observed in the research on the level of soil damage for biomass production relate to the variables stipulated in the Minister of Environment Regulation No. 07 of 2006 as shown in Table 1. Furthermore, there are two methods for determining soil damage for biomass production, namely the disturbed soil sample and the undisturbed soil aggregate method.

Table 1. Parameters, critical thresholds, measurement methods, and tools

Source: Minister of Environment Regulation No 07 of 2006 
The data obtained in the observation of soil damage for biomass production is analyzed by comparing it with the predetermined quality standards. The difference between the existing values shows the trend towards the level of damage in the existing soil.

\subsection{Ecosystem service valuation}

The evaluation of ecosystem service appraisal is performed in a participatory manner with experts that are very familiar with the research location and the opinions of community leaders. Furthermore, these opinions are then searched for the geometric mean before the pair comparison table using the Analytical Hierarchy Process (AHP). The next process is to use the Expert SA application to obtain the weights of the four ecosystem services and the value of consistency ratio (CR). Therefore, the $C R$ value must be $<0.1$.

In addition, the value of ecosystem services in the village area and their changes was assessed using Landsat images for 2000, 2010, 2015, and 2020. Land cover is divided into forest, mixed garden, agricultural land, water bodies, shrubs, open land, and built-up land. While the assessment of ecosystem services is focused on carbon stock, carbon sinks, biodiversity, land beauty, water management, and climate amelioration. These values are then averaged to obtain scores for the entire study location, and the image used is as follows.

- Year 2000 : Landsat 5

- LT05_L2SP_111067_19990923_20200907_02_T1_SR

- LT05_L2SP_110067_19980913_20200908_02_T1_SR

- Year 2010 : Landsat 5

- LT05_L2SP_111067_20091020_20200825_02_T1_SR

- LT05_L2SP_110067_20091013_20200825_02_T1_SR

- Year 2015 : Landsat 8

- LC08_L2SP_111067_20151106_20200908_02_T1_SR

- LC08_L2SP_110067_20151030_20200908_02_T1_SR

- Year 2020 : Landsat 8

- LC08_L2SP_111067_20190914_20200826_02_T1_SR

- LC08_L2SP_110067_20200824_20200905_02_T1_SR

To obtain the value of ecosystem services, the results of the classification of land use image are multiplied by the number of corrections shown in Table 2 (Rachdian et al., 2016).

Table 2. Correction rate for ecosystem service valuation

\begin{tabular}{lcccccc}
\hline \multirow{2}{*}{ No Land Use Type } & \multicolumn{5}{c}{ Average value of ecosystem services } \\
\cline { 2 - 7 } & Cstock & Csink & Biod & LB & WM & CA \\
\hline 1 Hutan (Forest) & 7 & 7 & 7 & 7 & 7 & 6 \\
2 Kebun Campuran (Mixed Farm) & 6 & 6 & 6 & 5 & 6 & 5 \\
3 Lahan Pertanian (Agricultural Land) & 4 & 4 & 5 & 4 & 4 & 4 \\
4 Badan Air (Water Body) & 1 & 1 & 4 & 6 & 1 & 7 \\
5 Semak (Bush) & 5 & 5 & 3 & 3 & 5 & 3 \\
6 Lahan Terbuka (Open Field) & 3 & 3 & 2 & 2 & 3 & 2 \\
7 Lahan Terbangun (Utilized Land) & 2 & 2 & 1 & 1 & 2 & 1 \\
\hline
\end{tabular}

Note: Cstock = Carbon stock, Csink = Carbon sink, Biod = Biodiversity, LB = Land beauty,

$\mathrm{WM}=$ Water Management, $\mathrm{CA}=$ Climate Amelioration

Furthermore, the value of ecosystem services obtained during the year of observation is calculated for the changes. To calculate changes in the value of ecosystem services, the following $V_{\text {change }}$ formula is used (Lu et al., 2015):

$$
\text { Vchange }=\frac{\text { Value2-Value1 }}{\mathrm{T}} \text {. }
$$

where $V_{\text {change }}$ is the change in the value of ecosystem services over time, Value1 and Value2 are the value of ecosystem services at times 1 and 2 , and $T$ is the lag time. The scoring criterion is at the 
point where $V_{\text {change }}=0$ or small, means the ecosystem is relatively healthy and sustainable. When there is a much increase, it results in weak sustainability, and when it is negative, the sustainability of ecosystem services is poor.

\section{Results}

\subsection{Livelihood assets of the Mamar community}

The results of the calculation of community livelihood assets which include human, natural, physical, financial, and social capital are presented in Table 3.

Table 3. Results of the analysis of community assets

\begin{tabular}{lrrrr|r|r|r}
\hline & Baumata & \multicolumn{2}{c}{ Oeletsala } & \multicolumn{2}{c}{ Camplong II Buraen } & \multicolumn{2}{c}{ Manubelon Average } \\
\hline HC & 7 & 5.8 & 6 & 8.33 & 6 & 6.626 \\
NC & 7.2 & 6 & 6.86 & 7.33 & 6 & 6.678 \\
PC & 7.6 & 6.6 & 7.4 & 8.3 & 7.7 & 7.52 \\
FC & 7.4 & 7.3 & 5.43 & 7 & 4.67 & 6.36 \\
SC & 6.8 & 6.6 & 6.86 & 8 & 7.67 & 7.186 \\
\hline
\end{tabular}

Overall, it is seen that the average value of financial capital has the lowest value for all study areas, followed by human, natural, social capital, and the highest is physical capital.

The comparison of the values of livelihood assets in the table is mapped into pentagon assets shown in Figures $2 a$ and $b$.

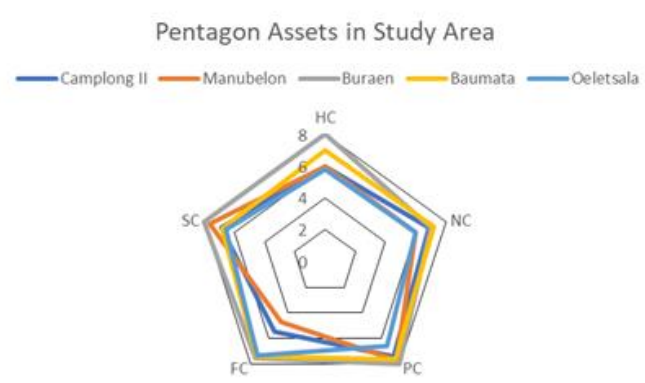

(a)

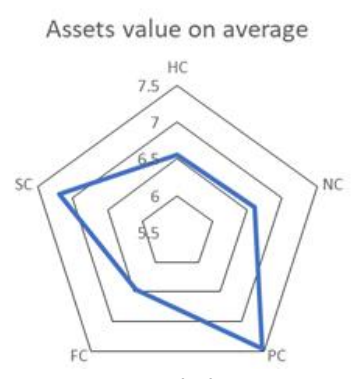

(b)

Figure 2. Pentagon assets in all study areas, showing the difference between an asset (a) and the mean value of assets from all study locations (b) in Kupang District.

\subsection{Community perception}

Based on the results of in-depth interviews, it is known that some farmers (30\%) are considering replacing the typical Mamar plants with crops of economic value, and the main consideration is the benefit value based on meeting economic needs. On the other hand, maintenance of Mamar is no longer performed strictly as stated in the customary rules (Banu), and it depends on the individual owner of the Mamar land.

The community acknowledges that the water discharge from the water source has been greatly reduced which also has an impact on meeting the needs of the community, especially the village of Oeletsala. Furthermore, the number of betel nut production in all study areas is acknowledged by the Buraen community since the infestation of the hornbill (Psyllidae) in 1998 is decrease. Meanwhile, in Oeletsala, the community stated that it was caused by high temperatures. Due to a significant shortage of betel production, the people of Timor generally import betel from outside the island.

Another major crop in Mamar is areca nut with a significantly reduced production, and the problem of climate variability is always used as an excuse for the community. However, based on the results of the observations made, it was seen that apart from climatic problems, mismanagement is a major factor causing the decline in existing areca plants. 


\subsection{Importance value index (IVI)}

The important data for the calculation of value index at the pole level and tree-level are presented in Tables 4 and 5.

a. Pole level

Table 4. Three species with the highest IVI at the pole level

\begin{tabular}{|c|c|c|c|c|c|c|c|c|}
\hline No & Species & $\mathrm{F}$ & $\operatorname{RF}(\%)$ & $\mathrm{D}$ & $\mathrm{RD}(\%)$ & Dom & RDom (\%) & IVI (\%) \\
\hline \multicolumn{9}{|c|}{ Baumata } \\
\hline & 1 Gmelina arborea Roxb. & 1.00 & 33.33 & 300 & 33.33 & 11.98 & 54.90 & 121.57 \\
\hline & 2 Averrhoa carambola & 1.00 & 33.33 & 400 & 44.44 & 6.01 & 27.57 & 105.35 \\
\hline & 3 Leucaena leucocephala & 0.50 & 16.67 & 100 & 11.11 & 1.91 & 8.76 & 36.54 \\
\hline \multicolumn{9}{|c|}{ Oeletsala } \\
\hline & 1 Areca catechu & 1.00 & 37.50 & 1900 & 46.34 & 18.84 & 32.21 & 116.05 \\
\hline & 2 Syzygium pycnanthum & 0.67 & 25.00 & 1900 & 46.34 & 29.02 & 49.63 & 120.97 \\
\hline & 3 Cocos nucifera & 0.33 & 12.50 & 100 & 2.44 & 4.84 & 8.28 & 23.22 \\
\hline \multicolumn{9}{|c|}{ Camplong II } \\
\hline & 1 Swietenia mahagoni & 1.00 & 22.22 & 1300 & 44.83 & 19.45 & 44.51 & 67.05 \\
\hline & 2 Tectona grandis & 0.50 & 11.11 & 700 & 24.14 & 5.05 & 11.57 & 46.82 \\
\hline & 3 Areca catechu & 0.50 & 11.11 & 400 & 13.79 & 4.87 & 11.14 & 36.05 \\
\hline \multicolumn{9}{|c|}{ Buraen } \\
\hline & 1 Areca catechu & 1.00 & 66.67 & 2300 & 92.00 & 32.64 & 88.97 & 247.64 \\
\hline & 2 Koompasia excelsa & 0.50 & 33.33 & 200 & 8.00 & 4.05 & 11.03 & 52.36 \\
\hline & $3-$ & - & - & - & - & - & - & - \\
\hline \multicolumn{9}{|c|}{ Manubelon } \\
\hline & 1 Areca catechu & 1.00 & 40.00 & 2700 & 79.41 & 36.74 & 63.27 & 182.68 \\
\hline & 2 Senna siamea & 0.50 & 20.00 & 500 & 14.71 & 12.81 & 22.05 & 34.71 \\
\hline & 3 Samanea saman & 0.50 & 20.00 & 100 & 2.94 & 4.84 & 8.34 & 31.28 \\
\hline
\end{tabular}

At pole level, the Areca catechu has a higher score at three locations namely Oeletsala, Buraen, and Manubelon, but lower at Camplong II and no value at Baumata.

b. Tree level

The results of calculation of the IVI at the tree level were presented in Table 5.

Table 5. Three species with the highest IVI at the tree level

\begin{tabular}{|c|c|c|c|c|c|c|c|c|}
\hline No & Species & $\mathrm{F}$ & $\mathrm{RF}(\%)$ & D & $\mathrm{RD}(\%)$ & Dom & RDom (\%) & IVI (\%) \\
\hline \multicolumn{9}{|c|}{ Baumata } \\
\hline & 1 Gmelina arborea Roxb. & 0.5 & 14.286 & 75 & 23.077 & 9.314 & 25.430 & 62.793 \\
\hline & 2 Morinda citrifolia & 1 & 28.571 & 50 & 15.385 & 5.848 & 15.967 & 59.923 \\
\hline & 3 Hibicus tiliaceus & 0.5 & 14.286 & 50 & 15.385 & 10.445 & 28.519 & 58.189 \\
\hline \multicolumn{9}{|c|}{ Oeletsala } \\
\hline & 1 Cocos nucifera & 1 & 30 & 350 & 51.852 & 27.358 & 30.465 & 112.317 \\
\hline & 2 Syzygium pycnanthum & 0.667 & 20 & 75 & 11.111 & 43.750 & 48.718 & 79.829 \\
\hline & 3 Arenga pinnata & 0.667 & 20 & 125 & 18.519 & 7.845 & 8.736 & 47.255 \\
\hline \multicolumn{9}{|c|}{ Camplong II } \\
\hline & 1 Cocos nucifera & 1 & 28.571 & 250 & 66.667 & 24.779 & 64.442 & 159.680 \\
\hline & 2 Swietenia mahagoni & 0.5 & 14.286 & 25 & 6.667 & 5.096 & 13.252 & 34.204 \\
\hline & 3 Hibicus tiliaceus & 0.5 & 14.286 & 25 & 6.667 & 2.632 & 6.846 & 27.798 \\
\hline \multicolumn{9}{|c|}{ Buraen } \\
\hline & 1 Cocos nucifera & 1 & 28.571 & 225 & 60 & 19.778 & 38.696 & 127.267 \\
\hline & 2 Maclura cochinchinensis & 1 & 28.571 & 75 & 20 & 14.293 & 27.965 & 76.537 \\
\hline & 3 Mangifera indica & 0.5 & 14.286 & 25 & 6.667 & 7.338 & 14.356 & 35.309 \\
\hline \multicolumn{9}{|c|}{ Manubelon } \\
\hline & 1 Borassus flabellifer & 0.5 & 20 & 500 & 74.074 & 9.702 & 28.277 & 122.351 \\
\hline & 2 Maclura cochinchinensis & 1 & 40 & 100 & 14.815 & 18.789 & 54.761 & 109.576 \\
\hline & 3 Cocos nucifera & 0.5 & 20 & 25 & 3.704 & 2.112 & 6.154 & 29.858 \\
\hline
\end{tabular}

At the tree level, the areca nut is no longer included in the top three dominant crops in all locations. 


\subsection{Shannon-Wiener Diversity Index}

The results of the calculation of the Shannon-Wiener diversity index are presented in Table 6.

Table 6. Shannon-Wiener Diversity Index at all study locations

\begin{tabular}{|c|c|c|c|c|c|}
\hline \multirow{2}{*}{ No } & \multirow{2}{*}{ Location } & \multicolumn{3}{|c|}{ Diversity } & \multirow{2}{*}{ Category } \\
\hline & & Seedling(s) & Sampling(s) & Pole(s) \& Tree(s) & \\
\hline \multicolumn{2}{|c|}{1 Baumata } & 1.084 & 1.459 & 1.893 & moderate \\
\hline \multicolumn{2}{|c|}{2 Oeletsala } & 1.420 & 1.985 & 1.614 & moderate \\
\hline \multicolumn{2}{|c|}{3 Camplong II } & 1.516 & 1.013 & 2.121 & moderate \\
\hline \multicolumn{2}{|c|}{4 Buraen } & 1.199 & 1.149 & 1.439 & moderate \\
\hline \multicolumn{2}{|c|}{5 Manubelon } & 1.369 & 1.84 & 1.195 & moderate \\
\hline
\end{tabular}

In Table 6, the vegetation diversity at all locations is classified as moderate and ranges from $1.195-2.121$ (in poles and trees).

\subsection{The level of soil damage for biomass production}

There are 10 parameters observed in determining the level of soil damage for biomass production, and the results are presented in Table 7.

Table 7. Results of Measurement for the level of soil damage for biomass production

\begin{tabular}{|c|c|c|c|c|c|c|c|c|c|c|}
\hline Location & $\begin{array}{c}\text { Solum } \\
(\mathrm{cm})\end{array}$ & $\begin{array}{l}\text { rockiness } f \\
\text { surface }(\%)\end{array}$ & $\begin{array}{l}\text { fraction } \\
\text { comp (\%) }\end{array}$ & $\begin{array}{l}\text { Vol. dens } \\
\text { (gr/cm3) }\end{array}$ & $\begin{array}{c}\text { Porosity } \\
\text { (\%) }\end{array}$ & $\begin{array}{c}\text { Permeab } \\
(\mathrm{cm} / \mathrm{h})\end{array}$ & $\mathrm{pH}$ & $\begin{array}{c}\mathrm{EC} \\
(\mathrm{mS} / \mathrm{cm})\end{array}$ & $\begin{array}{l}\text { Redox } \\
(\mathrm{mV})\end{array}$ & $\begin{array}{l}\text { Microbe } \\
10^{7} \mathrm{cfu} / \mathrm{g}\end{array}$ \\
\hline Baumata & 43.50 & 90.00 & 85.24 & $\quad 1.19$ & 55.28 & 8.80 & 6.60 & & -49.75 & \\
\hline Oeletsala & 26.67 & 28.33 & 31.00 & 0.86 & 67.72 & 8.57 & 6.64 & 54.87 & -42.00 & 98.00 \\
\hline Camplong & 45.00 & 75.00 & 25.20 & 0.87 & 67.22 & 8.05 & 6.63 & 69.15 & -41.50 & 115.00 \\
\hline Buraen & 23.00 & 32.50 & 66.39 & 0.86 & 67.70 & 6.52 & 6.68 & 39.90 & -35.25 & 114.50 \\
\hline Manubelon & 42.50 & 13.50 & 27.25 & 1.21 & 54.24 & 9.75 & 6.64 & 48.95 & -43.00 & 93.00 \\
\hline
\end{tabular}

From Table 7, it is known that there were several parameters (marked with an ellipse) that were classified as damaged because they have values that exceed the standards.

Baumata was the only research location that had five damaged parameters, followed by Camplong II which had four, Oeletsala and Manubelon had three damaged parameters, and the last is Buraen which only had two damaged parameters.

\subsection{Ecosystem services}

The ecosystem services were assessed using two approaches, namely, a participatory approach which specifically assesses Mamar ecosystem services, and a land cover analysis approach based on satellite imagery from Landsat 5 (2000 and 2010) and Landsat 8 (2015 and 2020).

\subsubsection{Participatory approach}

The results of the calculation of ecosystem services using a participatory approach involving forestry experts and community leaders are presented in Table 8.

Table 8. Values of ecosystem services based on the participatory approach

\begin{tabular}{|c|c|c|c|c|c|c|}
\hline \multirow{2}{*}{ No } & \multirow{2}{*}{ Location } & \multicolumn{4}{|c|}{ Ecosystem Services } & \multirow{2}{*}{ CR } \\
\hline & & Provision & Regulating & Cultural & Supporting & \\
\hline \multicolumn{2}{|c|}{1 Baumata } & 0.0773 & 0.1721 & 0.2394 & 0.5112 & 0.042 \\
\hline \multicolumn{2}{|c|}{2 Oeletsala } & 0.0773 & 0.2394 & 0.1721 & 0.5112 & 0.042 \\
\hline \multicolumn{2}{|c|}{3 Camplong II } & 0.187 & 0.0698 & 0.1372 & 0.606 & 0.094 \\
\hline \multicolumn{2}{|c|}{4 Buraen } & 0.0698 & 0.3242 & 0.1496 & 0.4564 & 0.049 \\
\hline \multicolumn{2}{|c|}{5 Manubelon } & 0.1281 & 0.0829 & 0.2563 & 0.5327 & 0.048 \\
\hline
\end{tabular}




\subsubsection{Land use analysis}

The results of the land use analysis are presented as follows.

\section{Baumata}

Land cover maps for 2015 and 2020 as well as graphs of changes in 2000, 2010, and 2020 in Baumata are shown in Figure 3.

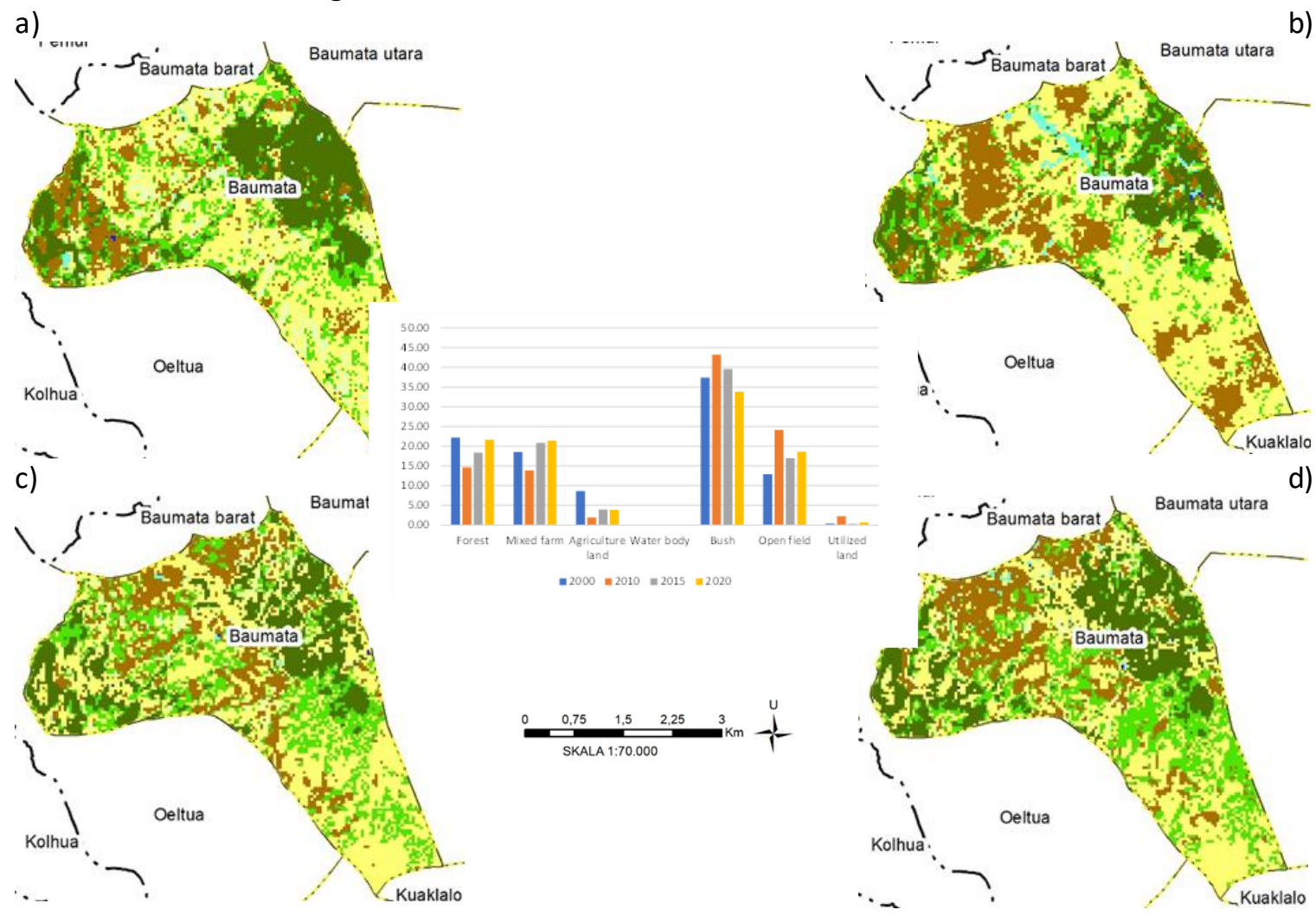

b)

Figure 3. The land-use change in Baumata based on satellite imagery analysis by year $(2000,2010$, 2015, and 2020).

Figure 3 shows the land-use change in Baumata based on satellite imagery analysis by year $(2000,2010,2015$, and 2020). Furthermore, the graph shows the highest percentage of forest which was in 2000 and decreased in 2010, and then increased in 2015 to 2020. 


\section{Oeletsala}

Figure 4 shows a map and graph of changes in land cover in Oeletsala in 2000,2010, 2015, and 2020.

a)

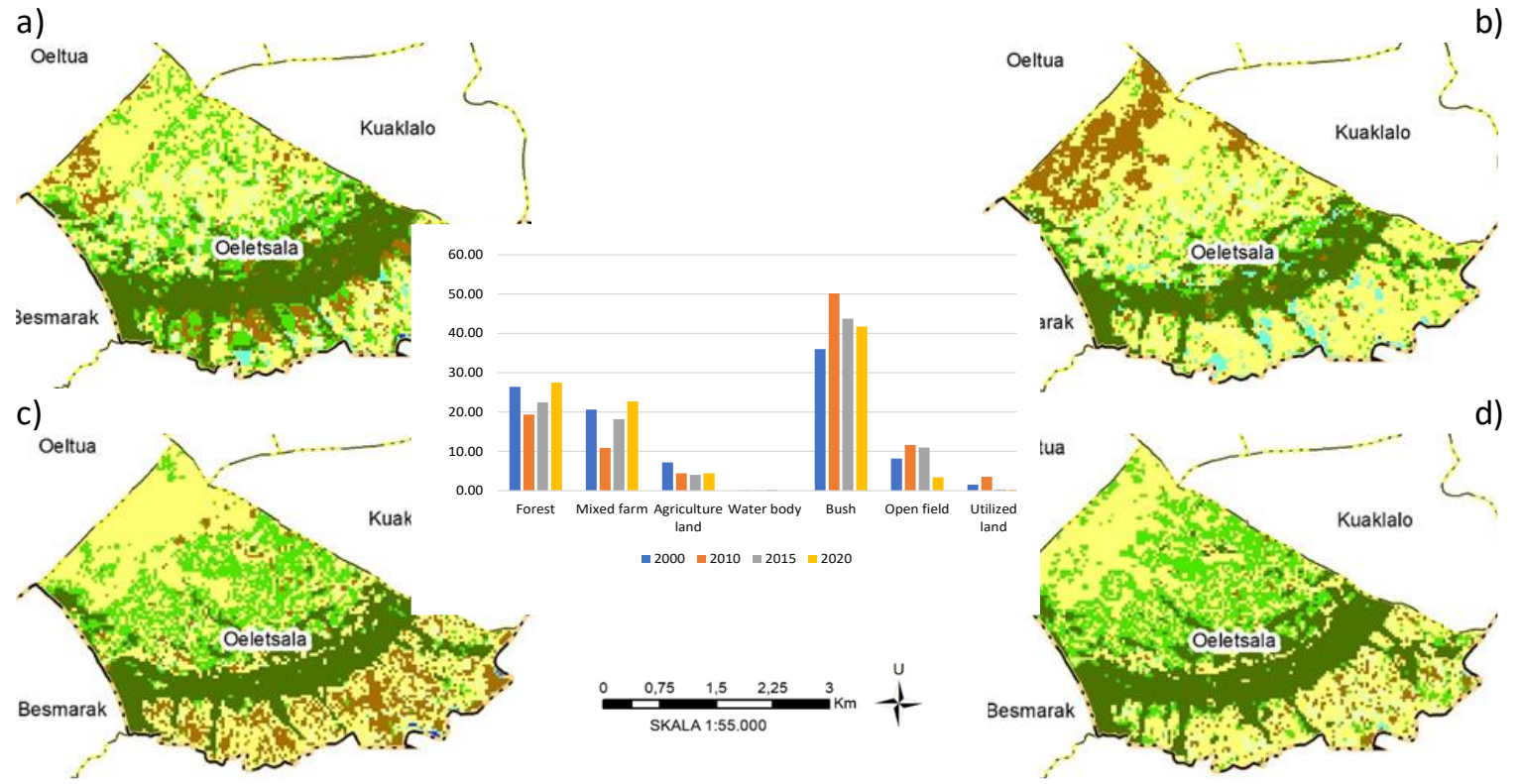

Figure 4. Land-use change in Oeletsala based on satellite imagery analysis by year $(2000,2010,2015$, and 2020).

The detail which can be seen in graphics show that the Oeletsala trend chart is similar to Baumata, but differs in detail.

\section{Camplong II}

Data and information related to changes in land cover in Camplong II village are shown in Figure 5.

a)

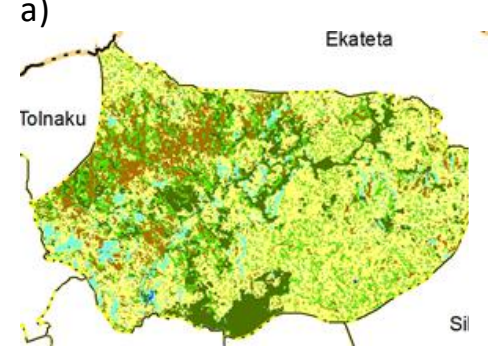

c)

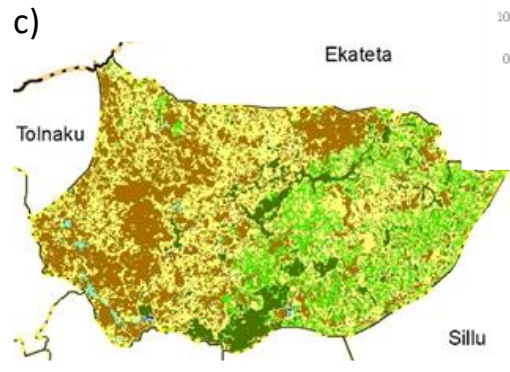

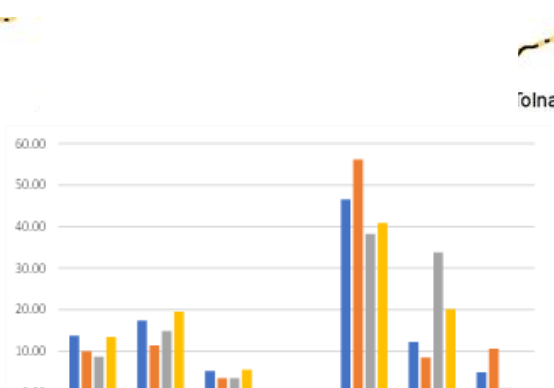

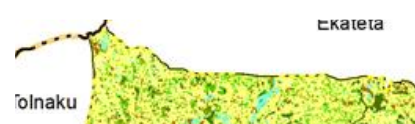

aku

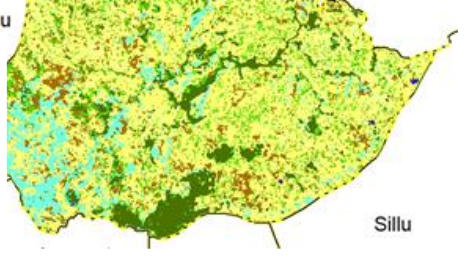

lu

d)

Figure 5. The changes in land use at Camplong II based on satellite imagery analysis by year: a) 2000, b) 2010 , c) 2015 , and d) 2020 ,

Figure 5. Shows the changes in land use at Camplong II based on satellite imagery analysis by year: a) 2000 , b) 2010 , c) 2015 , and d) 2020 , and the graph shows a very high percentage of shrubs and a relatively small area of forest. At the same time, the area of open land is relatively high as well as a mixed farm. 


\section{Buraen}

Figure 6 shows a map of changes in land cover in the village of Buraen, as well as a graph of changes in 2000, 2010, 2015, and 2020.

a)

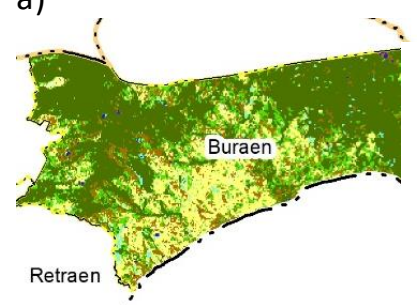

c)
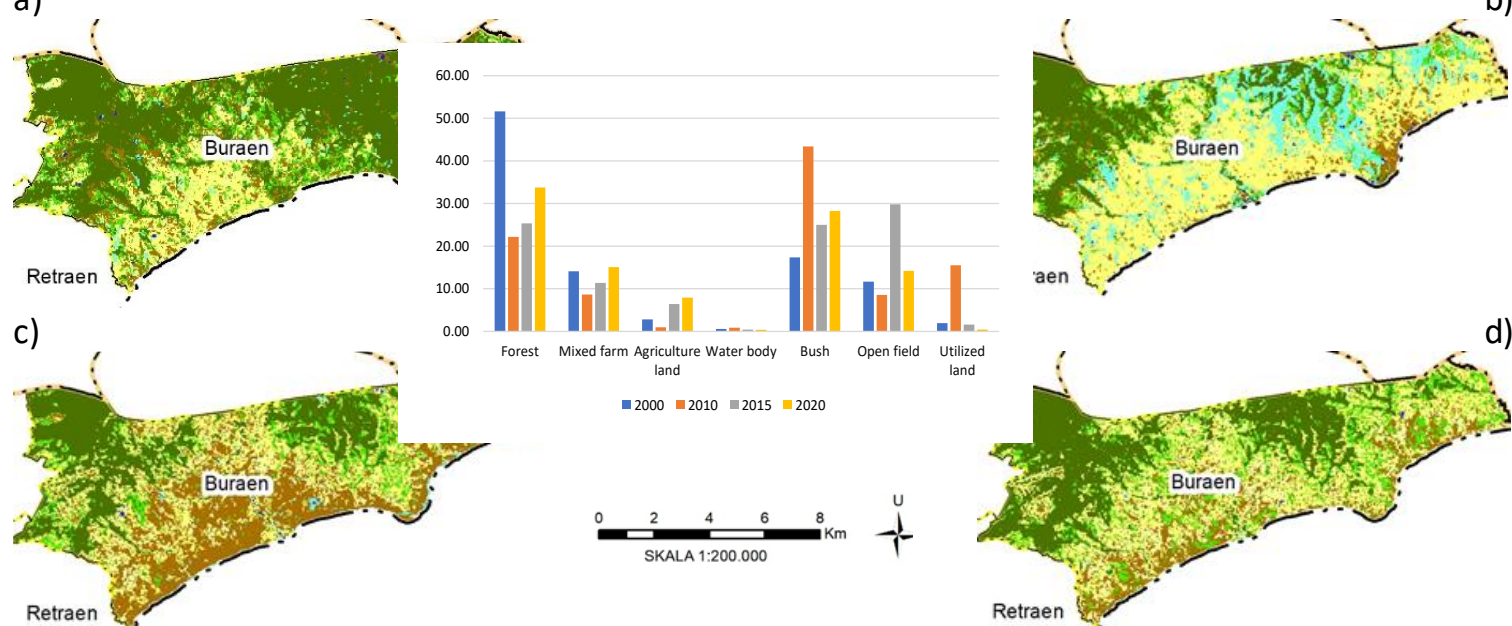

= $2000=2010=2015=2020$
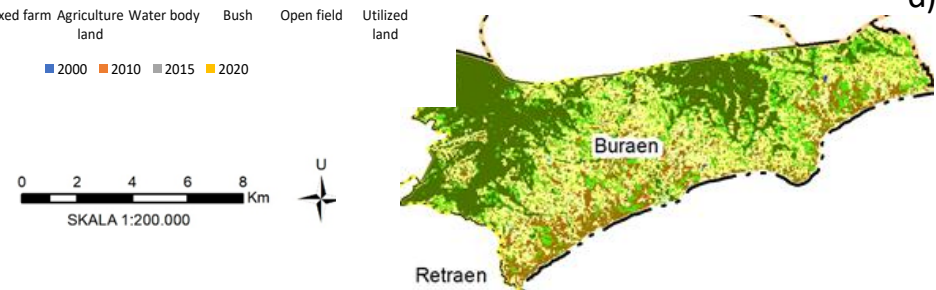

Figure 6. Changes in land cover in the village of Buraen, as well as a graph of changes in 2000, 2010, 2015, and 2020.

Unlike the previous locations, the graph in Figure 6 shows that the percentage of forest area in Buraen Village was the highest in 2000 compared to others. However, it decreased very significantly in 2010, combined with an increase in shrub area in 2010. In 2015 and 2020.

\section{Manubelon}

The maps and graphs of land cover changes in 2000, 2010, 2015, and 2020 in Manubelon are presented in figure 7 .

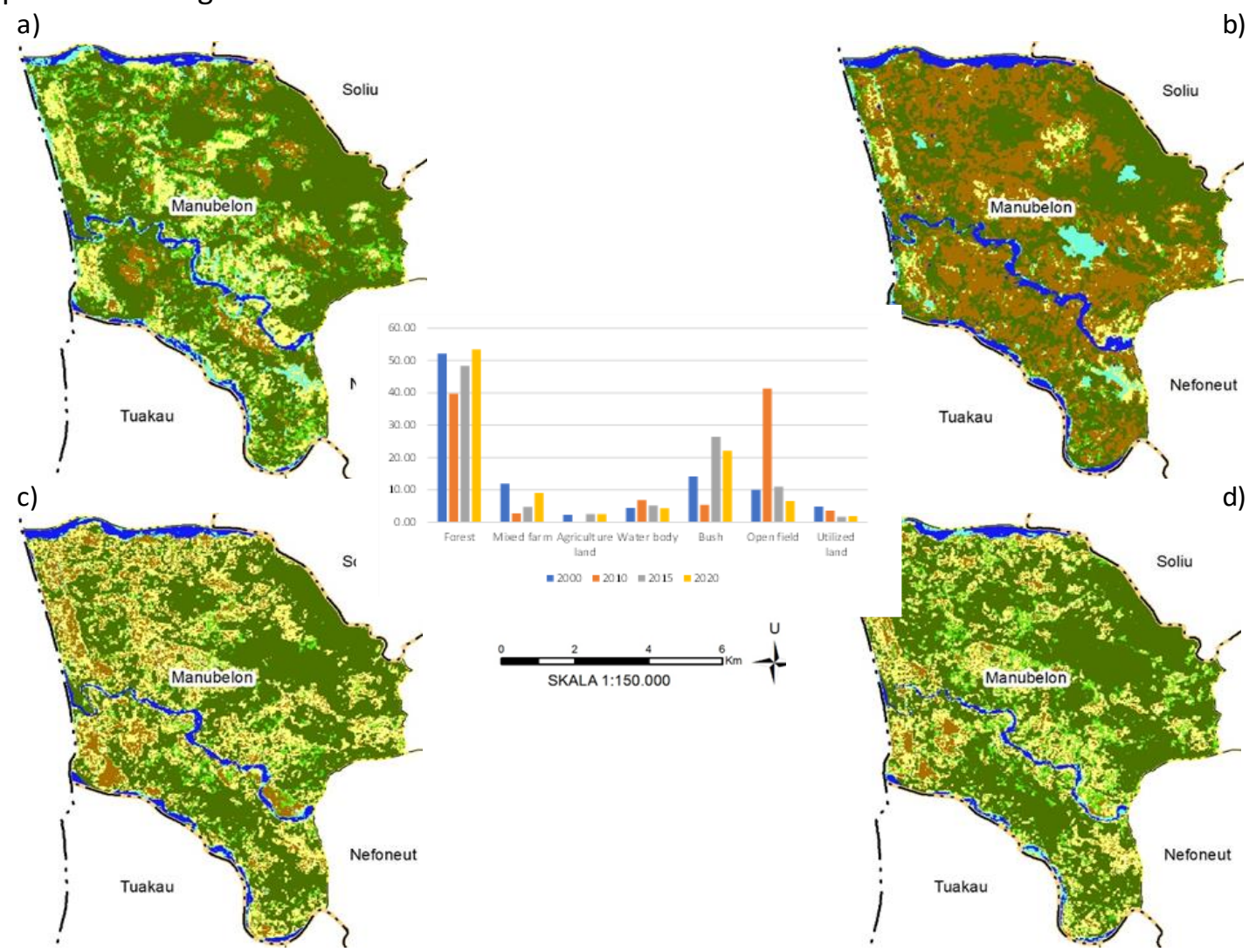

Figure 7. Manubelon's forest area is the highest of all study locations with the agricultural area being the lowest. 
3.6.3. Prediction of the value of ecosystem services based on the extent of land use types

Predictions of the value of ecosystem services using the area of land use based on the results of Landsat image analysis using the conversion rates in Table 2 as stated by (Rachdian et al., 2016) are presented in table 9.

Table 9. The Mean value of ecosystem services from all locations in 2000, 2010, 2015, and 2020

\begin{tabular}{cccccccc}
\hline Year & Cstock & Csink & Biod & LB & WM & CA & Average \\
\hline 2000 & 5.43 & 5.43 & 4.77 & 4.58 & 5.43 & 4.26 & 4.99 \\
2010 & 4.84 & 4.84 & 3.86 & 3.78 & 4.84 & 3.58 & 4.29 \\
2015 & 5.11 & 5.11 & 4.28 & 4.12 & 5.11 & 3.88 & 4.60 \\
2020 & 5.41 & 5.41 & 4.69 & 4.49 & 5.41 & 4.20 & 4.94 \\
\hline
\end{tabular}

Note: Cstock = Carbon stock; Csink = Carbon sink; Biod = Biodiversity; LB = Land beauty; $\mathrm{WM}=$ Water Management; $\mathrm{CA}=$ Climate Amelioration

Furthermore, Figure 8 shows the average value of ecosystem services according to the year of observation was presented in Figure 8.

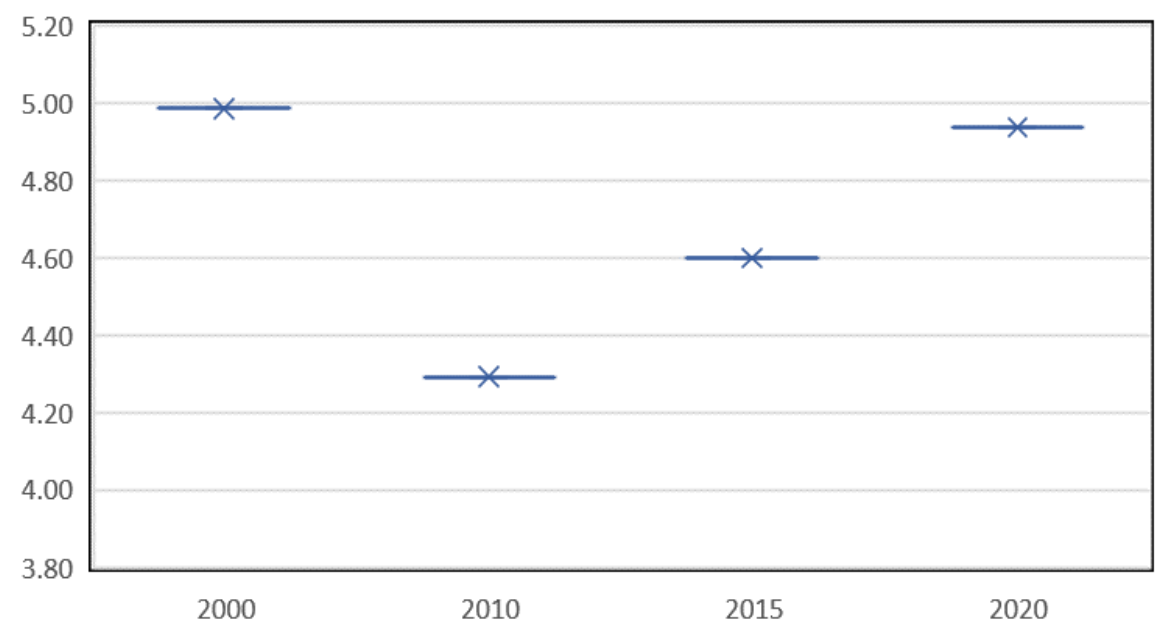

Figure 8. Shows the average value of ecosystem services by year which showed a downward trend in 2010 and increased in 2015 and 2020 Table 10.

The results of the calculation of changes in ecosystem services by period were presented in

Table 10. $V_{\text {change }}$ of each period

\begin{tabular}{rrr}
\hline No & Period & \multicolumn{1}{c}{ Vchange } \\
\hline 1 & $2000-2010$ & -0.07 \\
2 & $2010-2015$ & 0.062 \\
3 & $2015-2020$ & 0.068 \\
\hline
\end{tabular}

\section{Discussion}

\subsection{Livelihood assets}

The high level of physical assets represented by home ownership, living conditions, control of agricultural production facilities, and other assets such as cars, motorbikes, TVs, cell phones, gold jewelry, shows an orientation towards a modern lifestyle. Based on the results of in-depth interviews, it was discovered that ownership of these physical assets was also supported by the presence and contributions of families in other areas and the desire to have the same physical assets as those in the city. On the other hand, social capital which characterizes traditional rural 
communities shows a downward trend, which is caused by the influence of the surrounding environment which encourages mindset transformation. However, the value of social assets, in general, is still relatively high which contributes to community resistance to moral values, especially to maintain the sustainability of agroforestry. The habit of helping each other, which was identified as one of the social costs, was still relatively high and was recognized by all respondents in the study locations.

Ownership of other assets such as human, natural, and financial capital is relatively low. At first glance, this indicates the lack of progress in society. Human asset development $(\mathrm{HC})$, has been conducted among other things, by allowing children regardless of gender within the family to continue schooling outside the village. However, because of this, the availability of manpower to manage Mamar is limited. On the other hand, children that have completed their studies outside the village tend to look for work where there continue their studies even abroad. This also results in the unavailability of Mamar managers because it is only done by parents that have limited knowledge, skills, and personnel, and this condition in turn has a negative and positive impact. Furthermore, the negative impact is that Mamar is not managed properly, therefore it does not produce ecologically, economically, and socio-culture optimal benefit. The development of Mamar is also completely controlled by nature since old plants are not rejuvenated in a planned manner, therefore they grow and produce modestly. Unproductive old plants are used as building materials without replacement crops. In addition, the betel plant, which used to be one of the main crops, has become extinct in almost all study locations, so people have to buy from outside the island. According to the public's admission, this has been happening for a long time, especially since the introduction of the Psyllidae in 1989 as well as the very hot weather conditions.

The positive impact is that the land of Mamar is relatively undisturbed, therefore some of the moral values related to Mamar are believed to be preserved because it is considered an ancestral heritage apart from its ecological benefits. Managers which consist of old people, still uphold moral values from generation to generation, causing the Mamar area to exist.

The development of natural capital ownership, which in this study focuses on the use of Mamar, is also influenced by the conditions of human capital development. In financial asset ownership that examines savings, receivables, and loans of respondents, the majority $(>75 \%)$ of respondents stated that the hereditary habit (as part of the existing subsistence culture) to help each other as stated in the ownership of social assets, has an effect on ownership, and their financial assets. Deposits owned are relatively small due to the social costs and access to the bank which is considered a hassle. Some respondents $( \pm 30 \%)$ are interested in cooperatives, but there are still complaining about the existing services.

In the context of today's development, financial needs are important, because meeting economic needs is a priority. Furthermore, the condition of the low value of human capital has a double impact, namely (1) encouraging a paradigm shift in society and implicating changes in moral values, or (2) making society resistant to existing moral values. The first argument is supported by the fact that there is a decrease in the number of socio-cultural plants in Mamar to only $20-35 \%$ in all study areas, even when there are no more betel plants existing in the Baumata, Oeletsala, and Manubelon locations. The second argument is reinforced by the relatively high value of social capital, which shows the tendency of people to maintain their existing ancestral heritage, one of which is the fact that there are still many people from all regions (>60\%) that wants to maintain Mamar.

\subsection{Community perception}

It is known that Mamar Agroforestry complies Suek (2018), it is a form of local wisdom to protect and manage the environment in a sustainable manner, as well as a place to gather and socialize during water management. Furthermore, Mamar is also a habitat for plants that have become scarce due to land degradation on the island of Timor (Njurumana, 2012). Njurumana also stated that maintaining Mamar was the same as preserving the function of plant biodiversity. 
Meanwhile, socially and culturally, destroying Mamar's condition means denying the efforts of society to survive in the past, and especially denying the moral values that ever existed. The sociocultural values that are associated with Mamar's existence which distinguish it from agroforestry elsewhere are not remembered by future generations, although it is recognized that Mamar's presence is an inspiration in controlling the growth rate of critical land in NTT.

The tendency of expanding the community into existing land which is driven by economic interests (Muta'ali, 2019), poses a serious threat to existing ecosystem services. Furthermore, Mamar which is a biodiversity conservation unit (Njurumana, 2008) community based will also disappears. In the cases found in villages such as Oeletsala, Buraen, and Manubelon, the threat to the sustainability of Mamar is more of an economic importance, and the demand for life and lifestyle needs is seen to be a strong driving factor. According to the results of the interview, the tendency to convert Mamar land into plants with economic value does not come from people that are classified as poor. Therefore, this indicates a strong desire to get more income for fulfilling additional needs.

Changing this plant is categorized as an effort to simplify the types of biodiversity. If this is the case, there will be a reduction in environmental benefits, although it has a positive impact on the economy. In nutrient-poor climatic and soil conditions, this means a simplification of ecological characteristics and functions (Njurumana, 2009) which also causes loss of some of the existing germplasm or reducing diversity.

Another fact is the lack of good plant maintenance efforts, and this statement is supported by that of a farmer and a traditional leader in Oeletsala that stated that the existing Mamar has been greatly reduced. However, efforts to replant the main crops in Mamar were only made by a few residents that owned the land.

\subsection{Importance Value Index}

The important value index of the areca nut is still dominant at the pole level of the three locations, and not dominant at Camplong II, as well as not being found at the Baumata location. Furthermore, this occurs because many areca nuts at the tree levels died without a planned regeneration process such as customary rules that have been previously arranged. Customary rules which requires replanting plants to replace old, unproductive ones are no longer implemented. However, people tend to act on their own accord or care less about the development of Mamar. In addition, the diameter of the areca nut does not meet the requirements in the tree category since it is $<19 \mathrm{~cm}$ in size. This is because the growth of areca plants is not optimal (experiencing etiolation) due to the absorption of sunlight that is blocked by other plants.

\subsection{Shannon-Wiener Diversity Index}

The classified diversity index showed a decrease in vegetation when compared to the results of the Njurumana, (2009) study. This is possible due to two things, namely the existence of climate variability/the air temperature is higher, therefore the species is more specific (Nolan \& Callan, 2006) which occurs evenly in all study locations and human intervention in the form of activities in Mamar. This fact also suggests diminishing support for Mamar both natural and anthropogenic.

\subsection{Soil damage for biomass production}

There are five soil damage parameters for biomass production (see table 7), namely rockiness surface, fraction composition, permeability, electrical conductivity, and total microbes. Furthermore, Baumata is a location included in the five parameters which are classified as damaged, followed by Camplong with four parameters, then Oeletsala and Manubelon with three parameters, and Buraen with two parameters. The relatively slow rate of soil formation doesn't compensate for the high rate of erosion, which is one of the causes of the high percentage of rock on the surface. In addition, high activity and land use in Baumata and Camplong, which are natural tourism areas, also encourage high erosion, and the high composition of the soil fraction due to the loss of clay content due to erosion is as a result of erosion in Baumata. 
The texture, structure, and porosity of the soil causes damage to the permeability parameters (Sutanto, 2005 in Abdulkarim et al., 2015). Furthermore, soil texture which is dominated by high sand elements, and predominantly granular structure causes high permeability. Likewise, porous soil encourages high permeability. Based on observations, soil conditions in most of the study areas have these three factors, therefore the level of permeability in these areas is high. This is also driven by the leaching of soil colloids due to erosion which leaves a coarse fraction in the soil.

The EC value describes the salinity present in the soil, whereby its excessive amount inhibits the absorption of water and soil nutrients. The data obtained, it shows that all study areas have EC values that exceed the critical threshold or are classified as damaged. The high evaporation from the soil, which is driven by air temperature, allows mineral salts to rise through the soil capillaries, which has an impact on the accumulation of salt content thereby leading to a high EC value which has an impact on the inhibition of water and nutrient absorption due to osmotic pressure.

The total number of microbes is influenced by soil chemistry and physics, which will be high if the soil chemistry and physics are good, otherwise, poor soil chemical and physical conditions cause the total microbial count to be low (Abdulkarim et al., 2015).

\subsection{Ecosystem services}

Based on the data in table 8, the cultural service do not have a priority on the functionality of Mamar. Furthermore, this indicates that although Mamar was originally intended for water conservation and socio-cultural life, it has now changed. This condition is also a justification why people tend to think about the economic benefits generated. On the other hand, awareness of environmental functions means that people always want to maintain thick vegetation that no longer contains cultural values but is more economically valuable.

In terms of the resulting ecosystem services (from the analysis of land use), there is an interesting fact because the value of ecosystem services for all study locations shows a healthy trend towards sustainability for the period of 2010 - 2015 ( $\left.V_{\text {change }} 0.062\right)$ and 2015 - 2020 (0.068), after being classified as poor in the period $2000-2010\left(V_{\text {change }}-0.07\right)$. This turned out to be contributed by the area of land cover vegetation which increased in the period of 2010 - 2015 and $2015-2020$. Based on the results of interviews with local people, it was discovered that this was driven by deliberately made plantation, but with different types of Mamar vegetation, and accidentally because it grows naturally. This condition is an important finding that requires attention in the investigation of the specific factors causing it.

\section{Conclusions}

With the facts found, it can be seen that there is a tendency to reduce support for Mamar in socio-cultural functions, but support for ecological functions is still relatively good as indicated by the results of the analysis of the value of ecosystem services that look positive. This conclusion is based on the following findings: (1) reduced social capital; (2) there is a plan to change the types of plants in Mamar for economic benefits; (3) decrease in IVI of areca nut and betel as the main plants in Mamar; (4) vegetation diversity that decreased from high to medium; (5) there are several parameters that indicate soil damage, one of which is caused by the level of Mamar land use activity; and (6) changing priorities for the benefits of Mamar perceived by the community, namely cultural ecosystem services which are no longer a priority.

On the other hand, the value of ecosystem services based on the Vchange analysis is in a healthy status and has good sustainability in the period 2010 - 2015 and 2015 - 2020 due to natural factors and human efforts which generally occur outside the Mamar area. The low value of ecosystem services in the period $2000-2010$ was caused by the influence of climate variability.

In general, this condition shows the community's efforts to adapt to existing developments (economically oriented but trying to maintain ecology, although sacrificing socio-cultural aspects which have an impact on the blurring of the true meaning of Mamar). In conclusion, there is a socio- 
ecological trade-off that reduces support for the sustainability of Mamar as traditional agroforestry that emphasizes ons socio-cultural functions.

Author contributions: The author's contribution is as follows:

1. Alfred Umbu Kuala Ngaji: compiling, designing research, conducting data collection activities in the field, writing research results and publication manuscripts

2. Muhammad Baiquni: directing and designing research in the socio-cultural field (Universitas Gadjah Mada; mbaiquni@ugm.ac.id; https://orcid.org/0000-0002-3647-3286)

3. Hatma Suryatmojo: directs and designs research in the field of biotics (Universitas Gadjah Mada; hsuryatmojo@ugm.ac.id; https://orcid.org/0000-0003-1558-0290)

4. Eko Haryono: directs and designs research in the physical field, assists in the process of preparing manuscripts and is responsible for the correspondence process related to publication manuscript (Universitas Gadjah Mada; e.haryono@ugm.ac.id; https://orcid.org/0000-0002-4494-3065)

Competing interests: We declare that we have no competing interests.

Acknowledgments: I would like to thank the Director General of Higher Education who has provided funding for this research through the BPPDN scholarship. I also thank UGM for providing publication funds through the RTA program. Thanks also to Thomas Lapenangga, director of the state agriculture polytechnic of Kupang who facilitate this research, as well as to Yos Ruma, Charles Tlonanen, Deny Opat, Jemima, Rafael, and Yanto who helped collect biophysical data, and also to Mr. Aghni who helped in analyzing satellite imagery.

\section{Appendix 1}

Figure A2. Pentagon assets in all study areas showing the difference in asset value (a) and the mean value of assets from all study areas (b) in Kupang District.

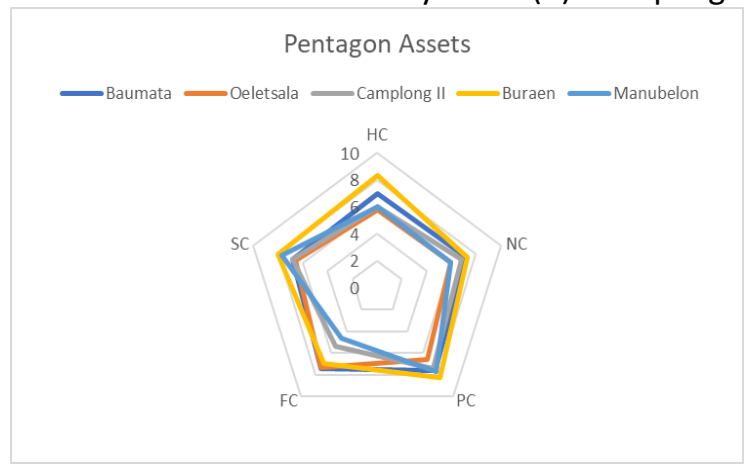

(a)

\begin{tabular}{lrrrrrr}
\hline & Baumata & \multicolumn{1}{c}{ Oeletsala } & Camplong II & Buraen & Manubelon & Average \\
\hline HC & 7 & 5.8 & 6.91 & 8.31 & 6.67 & 6.938 \\
NC & 7.2 & 6 & 7.09 & 7.08 & 6.44 & 6.762 \\
PC & 7.6 & 6.8 & 7.6 & 8.3 & 7.6 & 7.58 \\
FC & 7.4 & 7.3 & 5.82 & 6.92 & 5.33 & 6.554 \\
SC & 6.8 & 6.6 & 7.27 & 7.54 & 7.56 & 7.154 \\
\hline
\end{tabular}

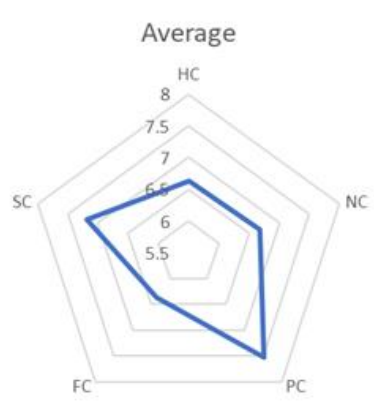

(b)

\begin{tabular}{lr}
\hline & Average \\
\hline HC & 6.938 \\
NC & 6.762 \\
PC & 7.58 \\
FC & 6.554 \\
SC & 7.154 \\
\hline
\end{tabular}

Figure A3. Land use change in Baumata displayed from data in table below

\begin{tabular}{lrrrr}
\hline & 2000 & 2010 & 2015 & 2020 \\
\hline Forest & 22.18 & 14.64 & 18.40 & 21.65 \\
Mixed farm & 18.53 & 13.84 & 20.83 & 21.41 \\
Agriculture land & 8.57 & 1.92 & 3.94 & 3.86 \\
Water body & 0.03 & 0.04 & 0.04 & 0.04 \\
Bush & 37.42 & 43.25 & 39.60 & 33.80 \\
Open field & 12.91 & 24.10 & 16.92 & 18.58 \\
Utilized land & 0.36 & 2.21 & 0.26 & 0.66 \\
\hline
\end{tabular}


Figure A4. Land use change in Oeletsala displayed from data in table below

\begin{tabular}{lrrrr}
\hline & 2000 & 2010 & 2015 & 2020 \\
\hline Forest & 26.43 & 19.36 & 22.48 & 27.47 \\
Mixed farm & 20.64 & 10.90 & 18.19 & 22.71 \\
Agriculture land & 7.17 & 4.39 & 4.03 & 4.43 \\
Water body & 0.09 & 0.07 & 0.22 & 0.02 \\
Bush & 36.02 & 50.15 & 43.74 & 41.72 \\
Open field & 8.14 & 11.61 & 11.00 & 3.39 \\
Utilized land & 1.52 & 3.52 & 0.34 & 0.25 \\
\hline
\end{tabular}

Figure A5. Land use change in Camplong II displayed from data in table below

\begin{tabular}{lrrrr}
\hline & 2000 & 2010 & 2015 & 2020 \\
\hline Forest & 13.75 & 9.95 & 8.68 & 13.44 \\
Mixed farm & 17.32 & 11.36 & 14.85 & 19.46 \\
Agriculture land & 5.20 & 3.45 & 3.53 & 5.46 \\
Water body & 0.06 & 0.09 & 0.11 & 0.13 \\
Bush & 46.55 & 56.16 & 38.19 & 40.88 \\
Open field & 12.18 & 8.46 & 33.77 & 20.11 \\
Utilized land & 4.94 & 10.53 & 0.86 & 0.51 \\
\hline
\end{tabular}

Figure A6. Land use change in Buraen displayed from data in table below

\begin{tabular}{lrrrr}
\hline & 2000 & 2010 & 2015 & 2020 \\
\hline Forest & 51.63 & 22.18 & 25.35 & 33.77 \\
Mixed farm & 14.10 & 8.62 & 11.38 & 15.09 \\
Agriculture land & 2.78 & 0.94 & 6.41 & 7.90 \\
Water body & 0.55 & 0.84 & 0.44 & 0.37 \\
Bush & 17.35 & 43.38 & 25.02 & 28.27 \\
Open field & 11.64 & 8.54 & 29.81 & 14.19 \\
Utilized land & 1.94 & 15.50 & 1.59 & 0.40 \\
\hline
\end{tabular}

Figure A7. Land use change in Manubelon displayed from data in table below

\begin{tabular}{lrrrr}
\hline & 2000 & 2010 & 2015 & 2020 \\
\hline Forest & 52.13 & 39.78 & 48.37 & 53.45 \\
Mixed farm & 11.90 & 2.69 & 4.81 & 9.08 \\
Agriculture land & 2.40 & 0.17 & 2.51 & 2.56 \\
Water body & 4.43 & 6.89 & 5.13 & 4.32 \\
Bush & 14.20 & 5.45 & 26.46 & 22.11 \\
Open field & 10.06 & 41.36 & 11.00 & 6.60 \\
Utilized land & 4.87 & 3.66 & 1.73 & 1.87 \\
\hline
\end{tabular}


Tabel A9. Mean value of ecosystem services from all locations in 2000, 2010, 2015, and 2020 (displayed from the average value from each category in each year of observation from table below) and also Figure A8. The average value of ecosystem services by year (displayed from the average value of each year).

\begin{tabular}{lccccccc}
\hline \multirow{2}{*}{ Location } & \multicolumn{7}{c}{2000} \\
\cline { 2 - 8 } & Cstock & Csink & Biod & LB & WM & CA & Average \\
\hline Baumata & 5.27 & 5.27 & 4.48 & 4.21 & 5.27 & 3.99 & 4.75 \\
Buraen & 5.83 & 5.83 & 5.39 & 5.24 & 5.83 & 4.73 & 5.48 \\
Camplong II & 5.00 & 5.00 & 3.95 & 3.73 & 5.00 & 3.59 & 4.38 \\
Manubelon & 5.61 & 5.61 & 5.34 & 5.28 & 5.61 & 4.81 & 5.38 \\
Oeletsala & 5.45 & 5.45 & 4.71 & 4.43 & 5.45 & 4.17 & 4.94 \\
\hline Average & 5.43 & 5.43 & 4.77 & 4.58 & 5.43 & 4.26 & 4.99 \\
\hline
\end{tabular}

\begin{tabular}{lccccccc}
\hline \multirow{2}{*}{ Location } & \multicolumn{7}{c}{2010} \\
\cline { 2 - 8 } & Cstock & Csink & Biod & LB & WM & CA & Average \\
\hline Baumata & 4.86 & 4.86 & 3.75 & 3.60 & 4.86 & 3.45 & 4.23 \\
Buraen & 4.85 & 4.85 & 3.78 & 3.70 & 4.85 & 3.49 & 4.25 \\
Camplong II & 4.79 & 4.79 & 3.51 & 3.37 & 4.79 & 3.27 & 4.09 \\
Manubelon & 4.61 & 4.61 & 4.26 & 4.37 & 4.61 & 4.04 & 4.41 \\
Oeletsala & 5.11 & 5.11 & 4.00 & 3.85 & 5.11 & 3.66 & 4.48 \\
\hline Average & 4.84 & 4.84 & 3.86 & 3.78 & 4.84 & 3.58 & 4.29 \\
\hline
\end{tabular}

\begin{tabular}{lccccccc}
\hline \multirow{2}{*}{ Location } & \multicolumn{7}{c}{2015} \\
\cline { 2 - 8 } & Cstock & Csink & Biod & LB & WM & CA & Average \\
\hline Baumata & 5.19 & 5.19 & 4.27 & 4.02 & 5.19 & 3.84 & 4.61 \\
Buraen & 4.90 & 4.90 & 4.16 & 3.99 & 4.90 & 3.74 & 4.43 \\
Camplong II & 4.58 & 4.58 & 3.51 & 3.33 & 4.58 & 3.24 & 3.97 \\
Manubelon & 5.51 & 5.51 & 5.04 & 5.07 & 5.51 & 4.63 & 5.21 \\
Oeletsala & 5.35 & 5.35 & 4.41 & 4.19 & 5.35 & 3.97 & 4.77 \\
\hline Average & 5.11 & 5.11 & 4.28 & 4.12 & 5.11 & 3.88 & 4.60 \\
\hline
\end{tabular}

\begin{tabular}{lccccccc}
\hline \multirow{2}{*}{ Location } & \multicolumn{7}{c}{2020} \\
\cline { 2 - 8 } & Cstock & Csink & Biod & LB & WM & CA & Average \\
\hline Baumata & 5.22 & 5.22 & 4.39 & 4.13 & 5.22 & 3.92 & 4.68 \\
Buraen & 5.44 & 5.44 & 4.82 & 4.59 & 5.44 & 4.26 & 5.00 \\
Camplong II & 4.99 & 4.99 & 4.02 & 3.77 & 4.99 & 3.64 & 4.40 \\
Manubelon & 5.77 & 5.77 & 5.40 & 5.37 & 5.77 & 4.88 & 5.50 \\
Oeletsala & 5.66 & 5.66 & 4.83 & 4.56 & 5.66 & 4.28 & 5.11 \\
\hline Average & 5.41 & 5.41 & 4.69 & 4.49 & 5.41 & 4.20 & 4.94 \\
\hline
\end{tabular}

Data in Table 10 comes from the difference in the average value of ecosystem services as a whole in two different years of observation divided by the time gap between the two observations.

For example, the calculation of the $\mathrm{V}_{\text {change }}$ value in the period $2000-2010$ is done by: the average in 2010 is 4.29 minus the average in 2000 which is 4.99 divided by 10 . The result is -0.07 , and so on.

\section{References}

Abdulkarim, M. N., Sariffuddin, \& Ardiansyah, S. Y. (2015). Penilaian dan Pemetaan Kerusakan Lahan untuk Produksi Biomassa di Kecamatan Mijen, Kota Semarang. Conference on Urban Studies and Development, 15-29. http://proceeding.cousd.org

Berkes, F., Colding, J., \& Folke, C. (2000). Rediscovery of Traditional Ecological Knowledge as Adaptive Management. Ecological Applications. https://doi.org/10.2307/2641280 
Castro, M. (2016). Management of agroforestry systems: ecological, social and economic approaches Esther Fernández-Núñez Marina Castro Editors (Issue December).

Fraser, E. D. G., Dougill, A. J., Hubacek, K., Quinn, C. H., Sendzimir, J., \& Termansen, M. (2011). Assessing vulnerability to climate change in dryland livelihood systems: Conceptual challenges and interdisciplinary solutions. Ecology and Society, 16(3), 01. https://doi.org/10.5751/ES03402-160303

Graves, A. R., Burgess, P. J., Palma, J. H. N., Herzog, F., Moreno, G., Bertomeu, M., Dupraz, C., Liagre, F., Keesman, K., van der Werf, W., de Nooy, A. K., \& van den Briel, J. P. (2007). Development and application of bio-economic modelling to compare silvoarable, arable, and forestry systems in three European countries. Ecological Engineering, 29(4), 434-449. https://doi.org/10.1016/j.ecoleng.2006.09.018

Intergovernmental Panel on Climate Change. (2013). Climate Change 2013: The Physical Science Basis. Contribution of Working Group I to the Fifth Assessment Report. In Climate Change 2013: The Physical Science Basis. Contribution of Working Group I to the Fifth Assessment Report.

Lu, Y., Wang, R., Zhang, Y., Su, H., Wang, P., Jenkins, A., Ferrier, R. C., Bailey, M., \& Squire, G. (2015). Ecosystem health towards sustainability. Ecosystem Health and Sustainability. https://doi.org/10.1890/EHS14-0013.1

MA, M. A. (2005). Ecosystem and Human Well-being. In W. V. Reid (Ed.), WHO (Vol. 256, Issue 6). https://doi.org/10.1152/ajpcell.1989.256.6.c1120

Mayrowani, H., \& Ashari, N. (2016). Pengembangan Agroforestry untuk Mendukung Ketahanan Pangan dan Pemberdayaan Petani Sekitar Hutan. Forum Penelitian Agro Ekonomi. https://doi.org/10.21082/fae.v29n2.2011.83-98

Moss, R. H., Edmonds, J. A., Hibbard, K. A., Manning, M. R., Rose, S. K., Van Vuuren, D. P., ... \& Wilbanks, T. J. (2010). The next generation of scenarios for climate change research and assessment. Nature, 463(7282), 747-756. https://doi.org/10.1038/nature08823

Muta'ali, L. (2019). Daya Dukung dan Daya Tampung Lingkungan Hidup Berbasis Jasa Ekosistem untuk Perencanaan Lingkungan Hidup (V. Eris (ed.); 1st ed.). Badan Penerbit Fakultas Geografi UGM. www.geo.ugm.ac.id

Natonis, M. (2008). Ekosistem Mamar. Accessed from http://marthennatonis.blogspot.com/2008/10/ekosistem-mamar.html

Ngaji, A. U. K., Baiquni, M., Suryatmojo, H., \& Haryono, E. (2020). Sustaining subsistence culture in Mamar agroforestry management in West Timor, is it possible? E3S Web of Conferences. https://doi.org/10.1051/e3sconf/202020002023

Njurumana, G. N., Victorino, B. A., \& Pratiwi, P. (2008). Potensi Pengembangan Mamar sebagai Model Hutan Rakyat dalam Rehabilitasi Lahan Kritis di Timor Barat. Jurnal Penelitian Hutan dan Konservasi Alam, 5(5), 473-484. https://doi.org/10.20886/jphka.2008.5.5.473-484

Njurumana, G. N. (2008). Kajian Degradasi Lahan Pada Daerah Aliran Sungai Kambaniru, Kabupaten Sumba Timur. Balai Penelitian Kehutanan Kupang, 241-254. Retrieved from http://www.forda-mof.org/files/5_Gerson_klm.pdf

Njurumana, G. N. (2009). Pola Pengelompokan Komunitas Mamar di Timor. Fakultas Pertanian UGM.

Njurumana, G. N. (2012). Agroforest Mamar dan Konservasi Keragaman Hayati Tumbuhan di Nusa Tenggara Timur. In Widiyatno, E. Prasetyo, T. S. Widiyaningsih, \& D. P. Kuswantoro (Eds.), Prosiding Seminar Nasional Agroforestry III (pp. 36-40).

Nolan, K. ., \& Callan, J. . (2006). Beachcomber Biology : The Shannon-Weiner Species Diversity Index. ABLE 2005 Proceedings, 27, 334-338.

Petheram, L., Zander, K. K., Campbell, B. M., High, C., \& Stacey, N. (2010). "Strange changes": Indigenous perspectives of climate change and adaptation in NE Arnhem Land (Australia). Global Environmental Change. https://doi.org/10.1016/j.gloenvcha.2010.05.002

Pujiono, E., Raharjo, S. A. S., Njurumana, G., Dwi, B., \& Rianawati, H. (2013). Kajian Aspek Ekologi, 
Ekonomi Dan Sosial Model-Model Agroforestri Di Nusa Tenggara Timur. In In: Prosiding Seminar Nasional Agroforestri (pp. 456-461).

Rachdian, A., Prasetyo, L. B., \& Rushayati, S. B. (2016). Identifikasi Perubahan Jasa Lingkungan dengan Menggunakan Penginderaan Jauh dan Sistem Informasi Geografis di Bogor. Media Konservasi, 21(1), 48-57. https://doi.org/10.29244/medkon.21.1.48-57

Rigueiro-Rodríguez, A., Mosquera-Losada, M. R., \& Fernández-nuñez, E. (2012). Afforestation of agricultural land with pinus radiata d. Don and betula alba I. In nw spain: Effects on soil ph, understorey Production and floristic diversity eleven years after establishment. Land Degradation and Development, 23(3), 227-241. https://doi.org/10.1002/ldr.1072

Roshetko, J., Mulawarman, S. W., \& Oka, I. N. (2002). Wanatani di Nusa Tenggara: Prosiding Loka Karya Wanatani Se-Nusa Tenggara 11-14 November 2001, Denpasar, Bali. Bogor: International Centre for Research in Agroforestry dan Winrock International. p, 164.

Ruhimat, I. S. (2015). Status Keberlanjutan Usahatani Agroforestry Pada Lahan Masyarakat: Studi Kasus Di Kecamatan Rancah , Kabupaten Ciamis, Provinsi Jawa Barat (Sustainability Status of Agroforestry in Private Lands : A Case Study in Rancah, Ciamis Regency, West Java). Penelitian Sosial Ekonomi Kehutanan, 12(2013), 99-110. https://doi.org/10.20886/jpsek.2015.12.2.99110

Suek, J. (2018). Resiko, Inefisiensi dan Keberlanjutan Sistem Wanatani di Wilayah Timor Barat. Universitas Gadjah Mada.

Sumu, Y. (2011). Mamar "Sistem Wanatani Asli Pulau Timor."

Tjoe, Y. (2016). Sustaining Livelihoods: An Analysis of Dryland Communities in West Timor, Indonesia Submitted in fulfilment of the requirements of the degree of (Issue March).

Wang, L., Zheng, H., Wen, Z., Liu, L., Robinson, B. E., Li, R., Li, C., \& Kong, L. (2019). Ecosystem service synergies/trade-offs informing the supply-demand match of ecosystem services: Framework and application. Ecosystem Services, 37(September 2018), 100939. https://doi.org/10.1016/j.ecoser.2019.100939

Wolf, J., Allice, l., \& Bell, T. (2013). Values, climate change, and implications for adaptation: Evidence from two communities in Labrador, Canada. Global Environmental Change. https://doi.org/10.1016/j.gloenvcha.2012.11.007

Zomer, R. J., Neufeldt, H., Xu, J., Ahrends, A., Bossio, D., Trabucco, A., Van Noordwijk, M., \& Wang, M. (2016). Global Tree Cover and Biomass Carbon on Agricultural Land: The contribution of agroforestry to global and national carbon budgets. Scientific Reports, 6 . https://doi.org/10.1038/srep29987 